\title{
KETANGGUHAN RETAK, KEKERASAN DAN KONDUKTIVITAS IONIK CSZ SEBAGAI ELEKROLIT PADAT SOFC DENGAN PENAMBAHAN CuO
}

\author{
Ila Lailatun Sholihah', Dani Gustaman Syarif ${ }^{2}$, Andhy Setiawan' \\ ${ }^{1}$ Program Studi Fisika, Jurusan Pendidikan Fisika-UPI JI.Dr. Setiabudhi 229, Bandung 40154 \\ 2 Pusat Sains dan Teknologi Nuklir Terapan (PSTNT)-BATAN \\ Jl. Taman Sari 71, Bandung 40132 \\ E-mail : ila.lailatun92@gmail.com \\ Diterima: 16-06-2015 \\ Diterima dalam bentuk revisi: 19-05-2015 \\ Disetujui: 08-07-2015
}

\begin{abstract}
ABSTRAK
KETANGGUHAN RETAK, KEKERASAN DAN KONDUKTIVITAS IONIK CSZ SEBAGAI ELEKROLIT PADAT SOFC DENGAN PENAMBAHAN CuO. Penelitian mengenai pengaruh penambahan $\mathrm{CuO}$ terhadap konduktivitas ionik, kekerasan dan ketangguhan retak CSZ sebagai elektrolit padat SOFC telah dilakukan. CSZ didoping dengan $\mathrm{CuO}$ dengan konsentrasi 0,1 , dan $2 \%$ berat. Pelet CSZ yang didoping CuO dikompaksi dengan tekanan 4 ton $/ \mathrm{cm}^{2}$ dan disinter pada suhu $1475{ }^{\circ} \mathrm{C}$ selama 3 jam. Konduktivitas ionik diukur dengan menggunakan alat LCR meter. Konduktivitas ionik CSZ dengan doping 0 , 1, dan $2 \%$ berat $\mathrm{CuO}$ adalah 0,063 $\mathrm{mS} / \mathrm{cm} ; 0,110 \mathrm{mS} / \mathrm{cm}$; dan $0,082 \mathrm{mS} / \mathrm{cm}$. Kekerasan dan ketangguhan retak diukur dengan metode vickers menggunakan alat uji keras Zwick. Hasil kekerasan vickers berturut-turut 9,9 $\mathrm{GPa} ; 12,1 \mathrm{GPa}$; dan 10,5 GPa, dan ketangguhan retak berturut-turut $1,61 \mathrm{MPa} / \mathrm{m}^{0,5} ; 1,85$ $\mathrm{MPa} / \mathrm{m}^{0,5}$; dan $1,54 \mathrm{MPa} / \mathrm{m}^{0,5}$. Analisis struktur kristal dilakukan dengan menggunakan XRD. Hasil analisis menunjukkan bahwa keramik yang dibuat berfase kubik FCC. Analisis struktur mikro dengan menggunakan mikroskop optik menunjukkan bertambahnya ukuran butir dengan peningkatan $1 \%$ berat $\mathrm{CuO}$. Secara keseluruhan penambahan $\mathrm{CuO}$ dengan konsentrasi $1 \%$ berat dapat memperbaiki sifat listrik dan sifat mekanik CSZ sebagai elektrolit padat
\end{abstract}

Kata kunci: Elektrolit padat SOFC, CSZ, konduktivitas ionik, kekerasan dan ketangguhan retak.

\section{ABSTRACT}

FRACTURE TOUGHNESS, HARDNESS AND IONIC CONDUCTIVITY OF CSZ AS SOLID ELECTROLYTE WITH ADDITION OF CuO. A research on effect of CuO addition on ionic conductivity, hardness and fracture toughness of CSZ as solid electrolyte had been conducted. CSZ was doped with 0,1 , and $2 \mathrm{wt} \% \mathrm{CuO}$. Pellets of $\mathrm{CuO}$ doped CSZ had been prepared by pressing with pressure of 4 ton $/ \mathrm{cm}^{2}$ and sintered at $1475^{\circ} \mathrm{C}$ for 3 hours. Ionic conductivity was measured by means of LCR meter. Ionic conductivity values of CSZ with doped 0,1 , and $2 \% \mathrm{CuO}$ were $0.063 \mathrm{mS} / \mathrm{cm}, 0.110 \mathrm{mS} / \mathrm{cm}$, and $0.082 \mathrm{mS} / \mathrm{cm}$. Hardness and fracture toughness were measured by vickers method using a hardness tester Zwick. The measured vickerss hardness were $9.9 \mathrm{GPa}, 12.1 \mathrm{GPa}$ and $10.5 \mathrm{GPa}$, and fracture toughness were $1.61 \mathrm{MPa} / \mathrm{m}^{0,5}, 1.85 \mathrm{MPa} / \mathrm{m}^{0,5}$, and $1.54 \mathrm{MPa} / \mathrm{m}^{0,5}$. Crystal structure analysis was done by using XRD. The analysis result showed that the prepared ceramics have cubic phase of FCC. Microstructure analysis by using an optical microscope showed that grain size increased with the increased of $1 \mathrm{wt} \% \mathrm{CuO}$. The addition of $\mathrm{CuO}$ at conscentration of $1 \mathrm{wt} \%$ can improve the electrical and mechanical properties of CSZ as solid electrolyte..

Keywords: SOFC solid electrolyte, CSZ, ionic conductivity, hardness and fracture toughness. 


\section{PENDAHULUAN}

Sampai saat ini Indonesia masih menggunakan minyak bumi yang berasal dari fosil sebagai sumber energi utama. Namun, keberadaannya sampai saat ini sebesar 3,5 miliar barel dan hanya cukup untuk memenuhi kebutuhan energi sampai 10 tahun kedepan (1). Berdasarkan latar belakang tersebut, maka diperlukan adanya sumber energi alternatif lain. Salah satunya dengan mengaplikasikan SOFC.

SOFC (Solid Oxide Fuel Cell) merupakan piranti elektronik berupa padatan keramik yang dapat mengubah energi kimia menjadi energi listrik dan panas (2-4). SOFC terdiri dari 3 komponen yaitu anode, katode dan elektrolit padat. Elektrolit padat merupakan komponen terpenting pada SOFC, karena merupakan tempat mengalirnya ion - ion oksigen dari katode menuju anode. Syarat elektrolit padat yang paling penting adalah memiliki konduktivitas ionik dan sifat mekanik yang baik (5).

Material yang sering digunakan sebagai elektrolit padat adalah zirkonia pada fasa kubik. Fasa kubik merupakan fasa zirkonia yang paling stabil untuk menghantarkan ion-ion oksigen (6). Namun, fasa kubik terjadi pada suhu tinggi $\left(2370{ }^{\circ} \mathrm{C}\right)(7)$, sehingga sulit untuk mengaplikasikannya. Oleh karena itu diperlukan upaya untuk menstabilkan zirkonia pada fasa kubik dengan suhu yang lebih rendah.

$\mathrm{CaO}$ merupakan material oksida yang sangat menarik karena keberadaannya yang melimpah di Indonesia dan dapat digunakan untuk menstabilkan zirkonia pada fasa kubik yang membentuk CSZ (Calsia Stabilized zirkonia) (8). Namun, nilai konduktivitas ionik dan sifat mekaniknya belum memenuhi standar elektrolit padat sehingga diperlukan upaya untuk meningkatkan nilai tersebut. Salah satunya, adalah dengan menambahkan aditif yang dapat meghasilkan kekosongan ion oksigen. CuO merupakan salah satu material yang secara teori dapat meningkatkan kekosongan ion oksigen. Adanya kekosongan ion oksigen tersebut dapat mempercepat proses sintering sehingga meningkatkan nilai konduktivitas ionik dan sifat mekanik. Studi tentang CSZ yaitu dengan doping $\mathrm{MgO}$ telah dilakukan oleh Hasanah (9), namun studi itu hanya difokuskan pada sifat listrik dengan konsentrasi dopan yang berbeda. Sehingga, dalam penelitian ini akan dibahas mengenai pengaruh penambahan $\mathrm{CuO}$ terhadap sifat mekanik yaitu kekerasan dan ketangguhan retak, sekaligus konduktivitas ionik CSZ.

\section{METODE PERCOBAAN}

Langkah pertama yaitu menimbang serbuk CSZ dan CuO dengan konsentrasi CuO 0 , 1, dan $2 \%$ berat. Masing-masing campuran digerus dengan bantuan alkohol supaya homogen selama \pm 1 jam. Kemudian campuran dikompaksi dengan tekanan sebesar 4 ton $/ \mathrm{cm}^{2}$ lalu disinter pada suhu $1475{ }^{\circ} \mathrm{C}$ selama 3 jam. Metode sintesis yang digunakan pada penelitian ini adalah metode reaksi zat padat yang juga digunakan pada penelitian lain $(2,8,9)$. Selanjutnya sampel dikarakterisasi dengan menggunakan XRD untuk mengetahui struktur kristal, dan dengan menggunakan Mikroskop optik Nikon Measurecope MM 22 yang dilengkapi alat pengukur Nikon SC-112 dan Mikroskop optik MEIJI TECHNO JAPAN 
yang dilengkapi dengan kamera Canon DS126371 DC 7,4 V untuk mengetahui struktur mikronya, konduktivitas ionik diukur dengan menggunakan alat LCR meter pada rentang frekuensi $20 \mathrm{~Hz}-5 \mathrm{MHz}$ yang diukur pada suhu $500{ }^{\circ} \mathrm{C}$. Sementara itu karakteristik mekanik (kekerasan dan ketangguhan retak) diukur menggunakan alat uji keras Zwick dengan metode vickers.

\section{HASIL DAN PEMBAHASAN}

\subsection{Analisis dan Struktur kristal}

Gambar 1 memperlihatkan pola XRD CSZ dan CSZ yang didoping $2 \%$ berat $\mathrm{CuO}$. Tujuan analisisis struktur kristal di sini adalah untuk memperlihatkan bahwa $\mathrm{CuO}$ dapat membentuk larutan padat dengan CSZ. Analisis struktur kristal CSZ yang didoping $2 \%$ berat CuO cukup mewakili analisis struktur kristal pengaruh penambahan doping $\mathrm{CuO}$ terhadap CSZ. Gambar 1 a dan $b$, tidak menunjukkan adanya puncak tambahan. Hal itu memperlihatkan bahwa CuO yang ditambahkan telah membentuk larutan padat dengan CSZ. Fase yang terbentuk adalah kubik FCC dengan nilai $\mathrm{h}^{2}$ $+\mathrm{k}^{2}+\mathrm{l}^{2}$ adalah $3,4,8,11,12,16,19$ dan 20. Parameter kisi dari CSZ dan CSZ yang didoping $2 \%$ berat $\mathrm{CuO}$ berturut-turut adalah $5,131 \AA ̊$ dan $5,133 \AA$.

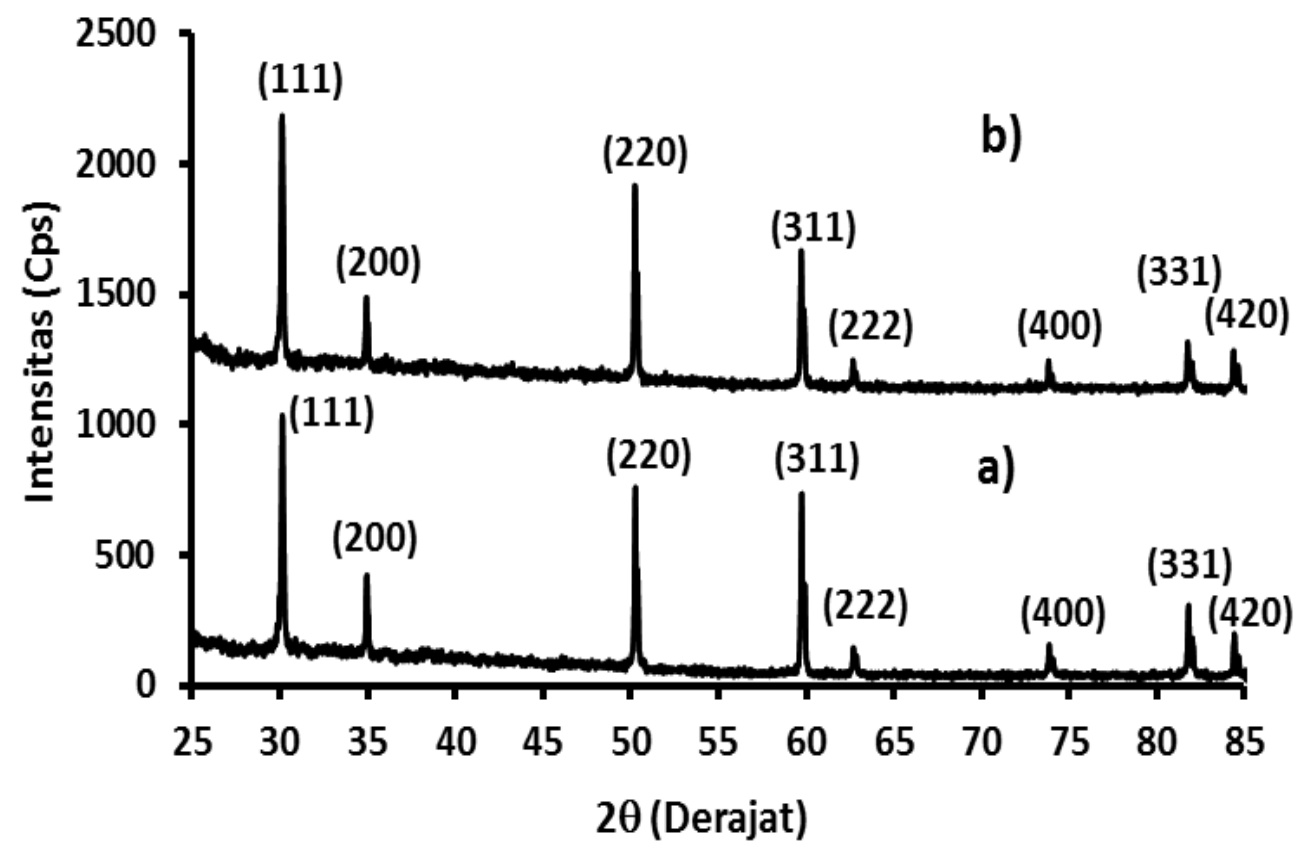

Gambar 1. Pola difraksi sinar-X (XRD). a) CSZ dan b) CSZ yang didoping $2 \%$ berat CuO.

\subsection{Analisis Struktur mikro}

Gambar 2, menunjukkan bahwa penambahan $1 \%$ berat $\mathrm{CuO}$ mengubah struktur mikro yang ditunjukkan dengan ukuran butir yang membesar dan porositas yang berkurang, didukung oleh rapat massa yang bertambah. Ukuran butir kembali ber-kurang dan porositas bertambah ketika konsentrasi $\mathrm{CuO}$ bertambah (menjadi 2\% berat). Dapat 
disimpulkan bahwa pe-nambahan $1 \%$ berat CuO merupakan penambahan paling optimum untuk memperbesar ukuran butir.

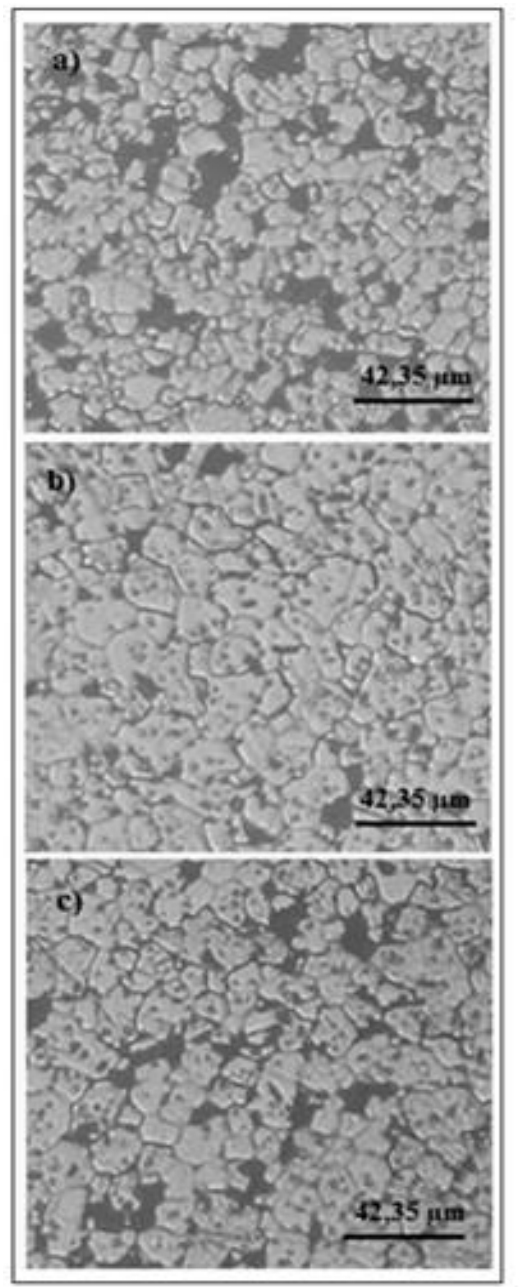

Gambar 2. Struktur mikro CSZ. (a) Tanpa doping, (b) Dengan doping $1 \%$ berat CuO, (c) Dengan doping $2 \%$ berat $\mathrm{CuO}$.

Tabel 1. Pengaruh $\mathrm{CuO}$ terhadap ukuran butir dan rapat massa CSZ

\begin{tabular}{cccc}
\hline No & $\begin{array}{c}\text { Penambahan } \\
\text { massa \% } \\
\text { berat CuO }\end{array}$ & $\begin{array}{c}\text { Ukuran } \\
\text { butir } \\
(\boldsymbol{\mu m})\end{array}$ & $\begin{array}{c}\text { Rapat } \\
\text { massa } \\
\left(\mathbf{g} / \mathbf{c m}^{3}\right)\end{array}$ \\
\hline 1 & 0 & 10 & 4,92 \\
2 & 1 & 14 & 5,15 \\
3 & 2 & 12 & 4,99 \\
\hline
\end{tabular}

\subsection{Analisis Sifat Listrik}

Gambar 3 memperlihatkan plot niquis (Nyquist plot) dari CSZ dan CSZ yang di-doping 2\% CuO. Dari Gambar 3 dapat dilihat bahwa pola niquis (kurva melengkung se-tengah lingkaran) CSZ yang didoping $1 \%$ berat $\mathrm{CuO}$ merupakan pola niquis yang paling kecil. Titik perpotongan antara pola niquis paling kanan dan sumbu mendatar (sumbu $\mathrm{x}$ ) mewakili tahanan ionik atau resistivitas ionik sampel. Resistivitas ionik berbanding terbalik dengan konduktivitas ionik, sehingga, CSZ yang didoping $1 \%$ berat CuO memiliki konduktivitas ionik paling besar. Hal itu didukung oleh data struktur mikro yang menunjukkan ukuran butir dan rapat massa yang bertambah. Ukuran butir dan rapat massa yang lebih besar menghasilkan konduktivitas ionik yang lebih besar karena pada sampel seperti itu transfer ion oksigen berlangsung lebih mudah (2).

Konduktivitas ionik sampel dengan konsentrasi $2 \%$ berat $\mathrm{CuO}$ lebih kecil dari pada konduktivitas ionik sampel dengan konsentrasi $1 \%$ CuO. Hal itu didukung oleh ukuran butir dan rapat massa yang mengecil kembali setelah konsentrasi $\mathrm{CuO}$ ditambah menjadi $2 \%$.

Ukuran butir dan rapat massa yang mengecil terjadi akibat $\mathrm{CuO}$ yang tidak larut pada konsentrasi $2 \%$ berat menghambat proses sintering dan pergerakan ion-ion oksigen. Nilai konduktivitas ionik CSZ yang didoping $1 \%$ berat $\mathrm{CuO}$ pada penelitian ini lebih besar dibandingkan dengan nilai konduktivitas ionik $\mathrm{CSZ}$ yang didoping $3 \%$ berat $\mathrm{La}_{2} \mathrm{O}_{3}$ 
$\left(0,051 \mathrm{mS} / \mathrm{cm}\right.$ pada suhu $\left.500{ }^{\circ} \mathrm{C}\right)(8)$, dan dengan nilai konduktivitas ionik CSZ yang ditambah 0,3\% berat MgO (9). Namun, nilai konduktivitas ionik CSZ yang didoping $1 \%$ $\mathrm{CuO}$ belum memenuhi standar konduktivitas ionik elektrolit padat $(0,3 \mathrm{mS} / \mathrm{cm}$ pada suhu $500{ }^{\circ} \mathrm{C}$ ) (2) dan lebih kecil dari pada konduktivitas ionik CSZ yang di doping $5 \%$ $\mathrm{Bi}_{2} \mathrm{O}_{3}(10)$.

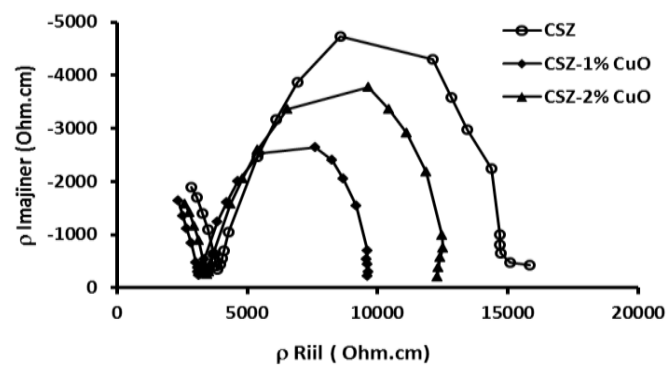

Gambar 3. Plot niquis (Nyquist plot) resistivitas imajiner terhadap resistivitas riil CSZ pada suhu $500{ }^{\circ} \mathrm{C}$.

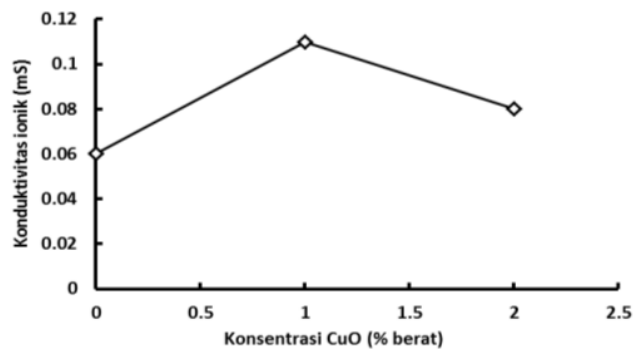

Gambar 4. Konduktivitas ionik CSZ terhadap $\mathrm{CuO}$ pada suhu $500^{\circ} \mathrm{C}$.

\subsection{Analisis Sifat Mekanik}

Gambar 5 (a dan b) dan Tabel 2 merupakan grafik dan nilai kekerasan vickers dan ketangguhan retak CSZ yang ditambah 0 , $1,2 \%$ berat $\mathrm{CuO}$. CSZ yang didoping $1 \%$ berat $\mathrm{CuO}$ memiliki nilai ke-kerasan dan ketangguhan retak yang paling besar. Kekerasan dan ketangguhan retak CSZ dengan penambahan $2 \%$ berat $\mathrm{CuO}$ lebih kecil.

Penurunan nilai kekerasan dan ketangguhan retak $\mathrm{CSZ}$ dengan $2 \% \mathrm{CuO}$, kemungkinan disebabkan oleh adanya $\mathrm{CuO}$ yang tidak larut yang menyebabkan butir tidak tumbuh sempurna pada saat proses sintering dan berdampak pada porositas yang berkurang sehingga keramik CSZ yang didoping $2 \%$ berat $\mathrm{CuO}$ menjadi lebih porus. Nilai kekerasan yang paling tinggi pada penelitian ini mendekati nilai kekerasan 8YSZ sebagai standar elektrolit padat yaitu 12,83 GPa. Namun, nilai ketangguhan retaknya masih jauh dari nilai ketangguhan retak 8YSZ yaitu 2,85 $\mathrm{MPa} / \mathrm{m}^{1 / 2}(11)$.
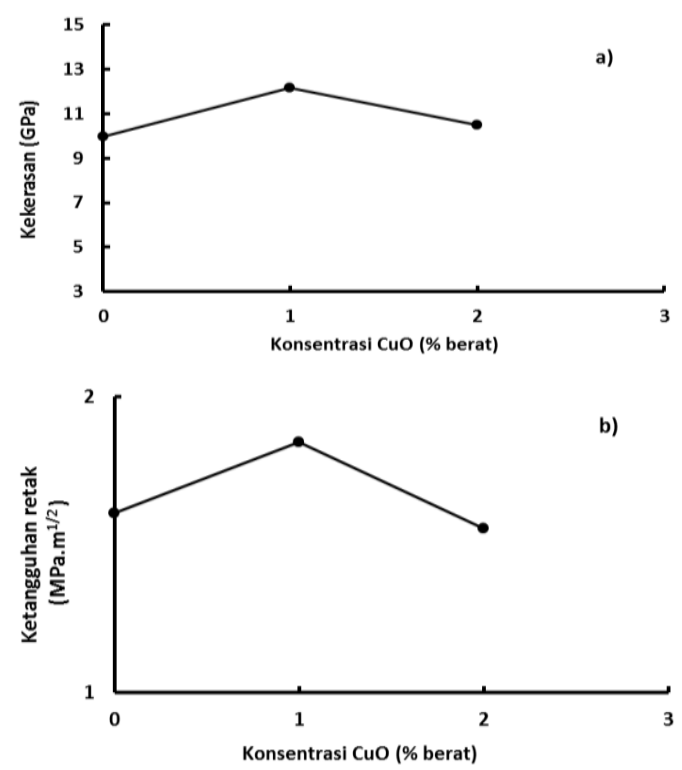

Gambar 5. Sifat mekanik CSZ dengan penambahan CuO. a) Kekerasan vickers, b) Ketangguhan retak.

Berdasarkan analisis sifat listrik dan sifat mekanik yang didukung dengan data struktur mikro, konsentrasi $1 \%$ berat $\mathrm{CuO}$ merupakan konsentrasi yang paling optimum untuk mendapatkan sifat listrik dan 
sifat mekanik CSZ yang besar sebagai elektrolit padat. Namun, nilai konduktivitas ionik, kekerasan dan ketangguhan retak yang didapatkan belum memenuhi standar elektrolit padat. Oleh karena itu diperlukan adanya penelitian lanjutan, baik dengan mengubah komposisi maupun dengan mengubah metode fabrikasi. Selain itu penambahan suhu sintering dan waktu sinter dapat dilakukan untuk mendapatkan nilai konduktivitas, kekerasan dan ketangguhan retak optimum yang dimiliki CSZ yang didoping $1 \%$ berat $\mathrm{CuO}$.

Tabel 1. Kekerasan vickers dan ketangguh-an retak.

\begin{tabular}{ccc}
\hline $\begin{array}{c}\text { Konsentrasi } \\
\text { CuO (\% berat) }\end{array}$ & $\begin{array}{c}\text { Kekerasan } \\
(\mathrm{GPa})\end{array}$ & $\begin{array}{c}\text { Ketangguhan } \\
\text { Retak (Mpa/m/2) }\end{array}$ \\
\hline 0 & 9,9 & 1,61 \\
1 & 12,1 & 1,85 \\
2 & 10,5 & 1,59 \\
\hline
\end{tabular}

\section{KESIMPULAN}

Berdasarkan hasil penelitian, penambahan $\mathrm{CuO}$ terhadap CSZ tidak mengubah struktur kristal dan tetap pada fasa kubik. Penambahan $\mathrm{CuO}$ hingga $1 \%$ berat dapat memperbesar nilai konduktivitas ionik dari $0,063 \mathrm{mS} / \mathrm{cm}$ menjadi $0,11 \mathrm{mS} / \mathrm{cm}$, kekerasan dan ketangguhan retak dari 9,9 GPa menjadi $12,1 \mathrm{GPa}$ dan $1,61 \mathrm{MPa} / \mathrm{m}^{1 / 2}$ menjadi $1,85 \mathrm{MPa} / \mathrm{m}^{1 / 2}$. Konduktivitas ionik, kekerasan, dan ketangguhan retak CSZ yang didoping $1 \%$ berat $\mathrm{CuO}$ pada peneliti-an ini belum memenuhi standar elektrolit padat. Oleh karena itu perlu dilakukan pe-nelitian lanjutan

\section{DAFTAR PUSTAKA}

1. Dahyaningsih E, Ibrahim R, dan Roesyadi A. Pembuatan biofuel dari minyak nyamplung (Calophyllum inophyllum L) melalui proses hydrocracking dengan katalis $\mathrm{Ni}$ Mo/Zeolit. Jurnal Teknik Pomits 2013; 2(1): 2301-9271.

2. Syarif DG, Soepriyanto $S$, Ismunandar, Korda AA. Effect of LSGM addition on electrical characteristics of $8 \mathrm{YSZ}$ ceramics for solid electrolyte. Journal of the Australian Ceramic Society 2013;49(2):52-59.

3. Letilly M, Joubert O, La Salle AL. Characterisation and optimisation of the cathode/electrolyte couple for SOFC LSCF/BIT07. Journal of Power Sources 2012;212:161-168.

4. Patakangas J, Ma Y, Jing $Y$, Lund $P$. Review and analysis of characterization methods and ionic conductivities for low-temperature solid oxide fuel cells (LT-SOFC). Journal of Power Sources 2014; 263: 315-331.

5. Jacobson AJ. Materials for solid oxide fuel cells. Chem. Mater. 2010; 22: 660674 DOI:10.1021/cm902640j.

6. Biswas M, Sadanala, Krishna Chaitanya. Electrolyte materials for solid oxide fuel cell. J Powder Metall Min 2013; 2: 117. doi:10.4172/21689806.1000117.

7. Aktas B, Tekeli S, Salman S. Crystallization and grain growth behavior of $\mathrm{La}_{2} \mathrm{O}_{3}$-doped yttriastabilized zirconia". Research Article Adv. Mat. Lett. 2014; 5(5): 260-264. 
8. Muslim P, Syarif DG, Setiawan A.

Pengaruh penambahan $\mathrm{La}_{2} \mathrm{O}_{3}$ terhadap konduktivitas ionik CSZ sebagai elektrolit padat. Jurnal Sains Materi Indonesia 2013;15(1):7-11.

9. Hasanah E. Pengaruh doping MgO terhadap konduktivitas ionik CSZ untuk elektrolit padat. Jurusan Fisika, UPI, 2014. (Sudah diterima untuk diterbitkan di Jurnal Ganendra, PSTA-BATAN).

10. Raghvendra, Singh $P$. Influence of $\mathrm{Bi}_{2} \mathrm{O} 3$ additive on the electrical conductivity of calciastabilized zirconia solid electrolyte.
Journal of the European Ceramic Society 2015;35:1485-1493.

11. Dudek M. Ceramic electrolytes in the $\mathrm{CeO}_{2}-\mathrm{Gd}_{2} \mathrm{O}_{3}-\mathrm{SrO}$ system-Preparation, properties and application for solid oxide fuel cells. Int. J. Electrochem. Sci. 2012; 7: 2874-2889. 
Jurnal Sains dan Teknologi Nuklir Indonesia

Indonesian Journal of Nuclear Science and Technology

Vol. 16, No 2, Agustus 2015; 85-92

ISSN 1411 - 3481 